\title{
Aplikasi Lactobacillus plantarum NHC6 sebagai Probiotik dalam Jus Nanas
}

\section{Application Lactobacillus plantarum NHC6 as a Probiotic in Pineapple Juice}

\author{
YOGY SATRIA ARIYANTO ${ }^{1}$, ANJA MERYANDINI ${ }^{1 *}$, TITI CANDRA SUNARTI² \\ ${ }^{1}$ Departemen Biologi, Fakultas Matematika dan Ilmu Pengetahuan Alam, Institut Pertanian Bogor, Kampus IPB \\ Dramaga, Bogor 16680 \\ ${ }^{2}$ Departemen Teknologi Industri Pertanian, Fakultas Teknologi Pertanian, Institut Pertanian Bogor, Kampus IPB \\ Dramaga, Bogor 16680
}

Diterima 8 September 2020/Disetujui 11 Januari 2021

\begin{abstract}
Probiotics are living microorganisms if consumed in sufficient quantities can be beneficial for health. One of the potential bacteria as probiotics is Lactobacillus plantarum NHC6 is a lactic acid bacteria isolated from pineapple juice. This study aimed to test the ability of $L$. plantarum $\mathrm{NHC6}$ as a probiotic in pineapple juice. Probiotics were stored until four weeks under $4^{\circ} \mathrm{C}$ and $10^{\circ} \mathrm{C}$ which weekly is monitored data on the amount of microbes, pH, percentage of lactic acid, and total dissolved solids in fermented pineapple juice. The result shows, the shelf time for pineapple juice under $4^{\circ} \mathrm{C}$ has a lower microbial reduction time rather than the juice storage under $10^{\circ} \mathrm{C}$. Probiotics shelf time predicted for $4^{\circ} \mathrm{C}$ storage was 28.32 weeks and for $10^{\circ} \mathrm{C}$ storage was 8.67 weeks after production. The changes in physical properties ( $\mathrm{pH}$, percentage of lactic acid, and total soluble solids) in $10^{\circ} \mathrm{C}$ storage is much faster than that off in $4^{\circ} \mathrm{C}$, this happens because there is still metabolic activity by bacteria at that temperature.
\end{abstract}

Key words: pineapple juice, Lactobacillus plantarum NHC6, storage, probiotic, viability

\section{PENDAHULUAN}

Probiotik didefinisikan sebagai mikroba hidup yang apabila dikonsumsi dalam jumlah yang cukup dapat bermanfaat bagi kesehatan (FAO/WHO 2006). Manfaat dari konsumsi probiotik dapat meningkatkan keseimbangan mikrobiom yang ada dalam saluran cerna dengan menekan mikroba yang dapat menimbulkan penyakit di dalam tubuh. Manfaat dari probiotik bergantung dari viabilitas mikroba dalam produk ataupun di dalam tubuh inang. Viabilitas ialah hal yang penting dalam suatu produk probiotik. Viabilitas probiotik dikatakan fungsional apabila dapat dikendalikan, mereduksi permeabilitas usus, dan imunomodulasi (Kosin dan Rakhsit 2006).

Bakteri-bakteriprobiotikberfungsimeningkatkan pertahanan pada saluran pencernaan untuk melindungi tubuh dari berbagai patogen (Bron et al. 2017). Probiotik dapat melindungi tubuh dengan cara menekan pertumbuhan melalui kompetisi dalam kolonisasi dan menghasilkan senyawa

*Penulis korespondensi:

E-mail: ameryandi@apps.ipb.ac.id metabolit yang dapat menghambat pertumbuhan patogen (Konig et al. 2016). Efek sistemik yang ditimbulkan oleh mikrob dimediasi oleh metabolit seperti Short Chain Fatty Acids (SCFAs) dan gas-gas seperti hidrogen sulfida, ammonia, hidrogen, metan, karbon monoksida, dan karbon dioksida. SCFA yang terutama terdiri atas asetat, propionat dan butirat diproduksi pada kondisi anaerob dari fermentasi serat pangan (Flint et al. 2012). SCFAs memiliki banyak pengaruh dalam tubuh inang, diantaranya berguna sebagai sumber energi, mendorong homeostatis glukosa dan energi, meregulasi respon imun dan inflamasi, meregulasi hormon anorektik yang berperan dalam kontrol rasa lapar, menekan tumor (khususnya butirat), dan meregulasi sistem saraf pusat dan tepi (Kim et al. 2013; Bienenstock et al. 2015). Selain itu, spesies bakteri komensal seperti L. plantarum dapat meregulasi integritas epitel usus dengan menstimulasi Toll-Like Receptor2 (TLR2) pada epitel usus yang berfungsi untuk meningkatkan sistem kekebalan tubuh (Karczewski et al. 2010).

Probiotik pada saat sekarang ini banyak diproduksi dengan bahan dasar berupa susu. Namun, tidak semua orang dapat mengkonsumsi susu contohnya orang-orang yang mengalami lactose intolerant yaitu kondisi yang menyebabkan 
ketidakmampuan untuk mencerna produk berbahan susu dengan baik. Selain itu, meningkatnya jumlah populasi masyarakat yang memilih gaya hidup sebagai vegan juga merupakan tantangan untuk produksi probiotik berbahan dasar selain susu. Sayur-sayuran dan buah-buahan dapat menjadi alternatif sebagai bahan pembuatan probiotik karena merupakan bahan pangan yang mengandung vitamin, mineral, serat pangan, antioksidan, dan senyawa bioaktif yang memiliki pengaruh positif pada organ-organ yang ada pada tubuh (Moraru et al. 2007), salah satunya adalah buah nanas.

Nanas (Ananas comosus L.) merupakan tanaman yang dapat tumbuh di negara beriklim tropis seperti Indonesia. Nanas memiliki manfaat untuk kesehatan karena mengandung mineral esensial dan vitamin C (Hossain et al. 2015). Vitamin $\mathrm{C}$ merupakan antioksidan primer yang larut air. Sebagai aktioksidan, vitamin $\mathrm{C}$ dapat melindungi sel dari pengaruh radikal bebas. Vitamin $\mathrm{C}$ yang terkandung di dalam buah nanas berkisar antara 9.2$93.8 \mathrm{mg} / 100 \mathrm{ml}$ dan dapat bervariasi bergantung dari kondisi tumbuh tanaman nanas tersebut (Camara et al. 1996). Minuman probiotik yang dibuat dari bahan nanas sudah pernah dilaporkan sebelumnya (AdebayoTayo dan Akpeji 2016; Nguyen et al. 2019).

Mikroba yang berpotensi dijadikan sebagai probiotik harus melewati uji in vitro terlebih dahulu yaitu, uji toleransi asam dan garam empedu, adhesi pada permukaan mukus dan jaringan epitel, memiliki aktifitas antibakteri melawan bakteri patogen, dan memiliki aktifitas hidrolase garam empedu sebelum dapat diaplikasikan dan dikomsumsi (Kechagia et al. 2013). L. plantarum NHC6 merupakan bakteri yang diisolasi dari nanas yang memiliki potensi dijadikan sebagai probiotik (Riani 2020). Bakteri ini memiliki karakteristik tahan terhadap kondisi asam dan garam empedu, memiliki aktivitas antimikroba terhadap bakteri patogen, peka terhadap antibiotik, memiliki kemampuan autoagregasi $94.73 \%$ dan koagregasi $35.63 \%$. Karakter dari L. plantarum NHC6 ini baik dijadikan sebagai kandidat starter probiotik.

L. plantarum NHC6 memiliki karakteristik yang berpotensi untuk dijadikan sebagai probiotik yang pada penelitian sebelumnya telah diuji pertumbuhannya dalam substrat asal isolasinya yaitu jus nanas. Bakteri ini mengalami pertumbuhan yang baik dalam jus nanas setelah diinkubasi selama 72 jam di suhu $37^{\circ} \mathrm{C}$ (Riani 2020). Berdasarkan dari penelitian tersebut, bakteri ini perlu diuji karakternya dalam jus nanas pada penyimpanan suhu komersial dan sekaligus untuk mengetahui masa simpannya berdasarkan jumlah minimal sel yang menjadi standar dalam produk probiotik. Penelitian ini bertujuan menguji kemampuan bakteri L. plantarum NHC6 sebagai probiotik yang disimpan pada suhu yang berbeda-beda dan memprediksi masa simpan probiotik dalam jus nanas.

\section{BAHAN DAN METODE}

Bahan Penelitian. Alat yang digunakan dalam penelitian ini adalah spektrofotometer UV/Vis, Laminar Air Flow Cabinet (LAFC), pH meter Hanna Instrument, laboratory $A B B E$ digital refractometer, chamber, lemari es, inkubator, shaker, water bath, oven, autoclave dan alat-alat gelas laboratorium. Bahan-bahan yang digunakan dalam penelitian ini meliputi isolat Lactobacillus plantarum NHC6, de Man, Rogosa and Sharpe (MRS) broth, agar-agar, nanas Honi Sunpride, fenolftalein, $\mathrm{NaOH} 0.1 \mathrm{~N}, \mathrm{NaOH} 4 \mathrm{~N}$, guar gum $0.1 \%$, standar $\mathrm{pH} 3$ dan 7 .

\section{Pengukuran Kurva Pertumbuhan} Lactobacillus plantarum NHC6. Koloni tunggal L. plantarum NHC6 diinokulasi ke dalam tabung ulir dengan media MRS broth sebanyak $5 \mathrm{ml}$. Inokulum diinkubasi di dalam shaker selama 11 jam pada suhu ruang $\left(29^{\circ} \mathrm{C} \pm 2^{\circ} \mathrm{C}\right)$ sampai OD bernilai 0.4 . Kemudian ke dalam erlenmeyer berisikan MRS broth $99 \mathrm{ml}$ diinokulasikan inokulum yang memiliki jumlah sel 5.28 log CFU/ml dengan OD 0.4 dan setiap 6 jam dilakukan perhitungan jumlah koloni menggunakan metode total plate count (TPC).

Pembuatan Jus Nanas. Buah nanas dikupas dan dicuci menggunakan aquades sampai bersih. Daging buah nanas dipotong kemudian dimasukkan ke dalam juicer untuk di ekstraksi. Jus nanas disaring untuk mengurangi serat kasar yang masuk ke dalam jus nanas. Jus nanas memiliki $\mathrm{pH}$ awal 3 yang kemudian dinaikkan dengan menambahkan $\mathrm{NaOH} 4 \mathrm{~N}$ sampai pH jus menjadi 6. Setelah itu ke dalam jus nanas ditambahkan hydrocolloid berupa guar gum sebanyak $0.1 \%$ (Mazumder et al. 2009). Jus nanas dimasukkan ke dalam botol steril sebanyak $99 \mathrm{ml}$ dan disterilisasi dengan cara pasteurisasi termal pada suhu $80^{\circ} \mathrm{C}$ selama 15 menit (Lagnika et al. 2017).

Aplikasi L. plantarum dan Penyimpanannya dalam Jus Nanas. Percobaan dilakukan dengan empat perlakuan yaitu penambahan starter probiotik dan tanpa starter sebagai kontrol serta penyimpanan yang dilakukan pada dua suhu yaitu $4^{\circ} \mathrm{C}$ dan $10^{\circ} \mathrm{C}$ selama empat minggu. Starter probiotik diambil dari inokulum berusia 24 jam (9 $\log \mathrm{CFU} / \mathrm{ml}$ ) sebanyak $1 \mathrm{ml}$ yang kemudian dimasukkan ke dalam jus $99 \mathrm{ml}$.

Model linear yang digunakan untuk memprediksi masa simpan probiotik berdasarkan reduksi jumlah mikroba (Muller et al. 2013). Prediksi ini berdasarkan reduksi jumlah mikroba secara eksponensial yang dipengaruhi oleh faktor suhu yang dapat dihitung melalui persamaan berikut: 


$$
\mathrm{Nt}=\mathrm{N}_{0} \mathrm{e}^{-\mathrm{kt}}
$$

$$
\begin{array}{ll}
\mathrm{Nt} & =\text { jumlah dari mikroba pada waktu ke } \mathrm{t} \\
\mathrm{N} 0 & =\text { jumlah mikroba pada waktu ke } 0 \\
\mathrm{k} & =\text { laju destruksi } \\
\mathrm{t} & =\text { waktu }
\end{array}
$$

Plotting $\ln (\mathrm{Nt} / \mathrm{N} 0)$ setiap waktu, dapat digunakan untuk menentukan nilai k untuk setiap suhu simpan. Pengaruh suhu terhadap nilai $\mathrm{k}$ dapat ditentukan berdasarkan persamaan Arrhenius berikut:

$$
\mathrm{k}=\mathrm{Ae}-{ }^{\mathrm{E} a / \mathrm{RT}}
$$

$$
\begin{array}{ll}
\mathrm{k} & =\text { laju destruksi }\left(\text { waktu }^{-1}\right) \\
\mathrm{A} & =\text { faktor frekuensi }\left(\mathrm{waktu}^{-1}\right) \\
\mathrm{R} & =\text { konstanta gas }\left(8.314 \mathrm{~J} \cdot \mathrm{mol}^{-1} \cdot \mathrm{K}^{-1}\right) \\
\mathrm{T} & =\text { suhu }(\text { Kelvin }) \\
\mathrm{Ea} & =\text { energi aktivasi }\left(\mathrm{J} \cdot \mathrm{mol}^{-1}\right)
\end{array}
$$

Dengan plotting $\ln (\mathrm{k})$ terhadap $1 / \mathrm{T}$, dapat diperoleh garis linear yang mengarah pada persamaan (2). Persamaan (3) dapat digunakan untuk memprediksi lama penyimpanan probiotik dalam jus nanas berdasarkan jumlah sel untuk setiap suhu penyimpananya. $\mathrm{k}$ juga terkait dengan waktu reduksi desimal $\left(\mathrm{D}_{1}\right)$ yaitu waktu saat populasi tereduksi $90 \%$ dari populasi inisialnya.

$$
\mathrm{D}_{1}=\ln _{10} / \mathrm{k}
$$

Dengan perpanjangan prediksi penyimpanan, juga dapat ditentukan jumlah sel tereduksi $99 \%$ dan $99.99 \%$ $\left(\mathrm{D}_{2}\right.$ dan $\left.\mathrm{D}_{3}\right)$.

Karakteristik Produk. Karakteristik produk yang diamati adalah konsentrasi bakteri, konsentrasi asam laktat, $\mathrm{pH}$ dan total padatan terlarut jus nanas. Total plate count merupakan metode yang digunakan dalam menghitung jumlah koloni (Nguyen et al. 2019). Sampel diencerkan dalam pengenceran serial kemudian disebar pada media MRS padat dan disimpan pada suhu ruang selama 48 jam. Sampel probiotik masing-masing suhu dihitung jumlah koloninya setiap minggu.

Total asam dihitung dengan cara titrasi. Sebanyak $1 \mathrm{ml}$ sampel diencerkan dengan $9 \mathrm{ml}$ aquades dan ditambahkan dengan fenolftalein $0.1 \mathrm{ml}$ kemudian di titrasi dengan $\mathrm{NaOH} 0.1 \mathrm{~N}$. Banyaknya asam laktat yang diperoleh dihitung menggunakan formula berikut (Suhaeni 2018):

$$
\text { Total Asam Laktat }=\frac{\text { V1.N.B.fp }}{\text { V2.1000 }} \times 100
$$

$$
\begin{array}{ll}
\mathrm{V} 1 & =\text { Volume } \mathrm{NaOH} \\
\mathrm{V} 2 & =\text { Volume sampel } \\
\mathrm{N} & =\text { Normalitas NaOH } \\
\mathrm{B} & =\text { Bobot molekul asam laktat } \\
\mathrm{fp} & =\text { Faktor pengenceran }
\end{array}
$$

$\mathrm{pH}$ probiotik diperoleh dengan menggunakan $\mathrm{pH}$ meter dan total padatan terlarut diperoleh dengan menggunakan refraktomerter $\left({ }^{\circ}\right.$ Brix $)$.

\section{HASIL}

Kurva Pertumbuhan Lactobacillus plantarum NHC6. Pertumbuhan L. plantarum NHC6 mencapai fase $\log$ pada 12 jam inkubasi dan mengalami fase stasioner setelahnya sampai 48 jam penyimpanan. Konsentrasi jumlah sel dalam kultur digunakan untuk proses produksi probiotik dengan memperhatikan jumlah sel minimum dalam jus nanas. Konsentrasi sel minimum yang harus ada dalam produk probiotik ialah $6 \log \mathrm{CFU} / \mathrm{ml}$ dan konsentrasi yang dibutuhkan dalam produksi minimum ialah $7 \log$ CFU/ml. Jumlah sel yang dipanen pada penelitian ini berjumlah 9 log $\mathrm{CFU} / \mathrm{ml}$. Untuk produksi sebanyak $100 \mathrm{ml}$ probiotik jus nanas dibutuhkan sebanyak $1 \%$ kultur bakteri yang dimasukkan pada saat produksi minuman probiotik. Konsentrasi inisial sel bakteri yang dimasukkan kedalam jus nanas ialah $7 \log$ CFU/ml (Gambar 1).

Karakter Jus Nanas difermentasi Lactobacillus plantarum NHC6. Jus nanas menjadi sumber substrat untuk pertumbuhan probiotik. Pertumbuhan teramati dengan bertambahnya jumlah sel pada dua minggu pertama penyimpanan sebelum terjadinya penurunan jumlah sel (Gambar 2a). Substrat pertumbuhan digambarkan sebagai total padatan terlarut yang mengandung berbagai sumber karbon di dalamnya (Gambar 2b). Probiotik yang disimpan pada suhu $4^{\circ} \mathrm{C}$, kontrol 4 dan $10^{\circ} \mathrm{C}$ relatif stabil untuk seluruh parameter yang diamati selama penyimpanan sedangkan probiotik yang disimpan pada suhu $10^{\circ} \mathrm{C}$ membuat perubahan pada parameter yang diamati pada jus nanas. Probiotik pada suhu $10^{\circ} \mathrm{C}$ menggunakan substrat pada dua minggu pertama penyimpanan yang terlihat dari penurunan total padatan terlarut secara eksponensial (Gambar 2b). Penurunan padatan terlarut diduga bahwa probiotik menggunakan substrat untuk pertumbuhan dan proses metabolisme primer. Metabolisme yang dilakukan oleh L. plantarum NHC6 ialah proses fermentasi yang menghasilkan asam laktat yang menyebabkan terjadinya penurunan nilai $\mathrm{pH}$ didalam jus nanas (Gambar 2c dan d).

Jumlah sel probiotik yang disimpan pada suhu $4^{\circ} \mathrm{C}$ mengalami penurunan pada minggu kedua sampai keempat masa penyimpanan. Penyimpanan pada suhu $4^{\circ} \mathrm{C}$ membuat pertumbuhan bakteri terhambat dan tidak memengaruhi karakter jus nanas dibandingkan dengan kontrol (Gambar 2). Jumlah sel probiotik yang disimpan di suhu $10^{\circ} \mathrm{C}$ mengalami penurunan dan perubahan karakter jus nanas pada minggu ketiga sampai masa akhir penyimpanan.

Model Reduksi Mikroba. Kerusakan sel didalam jus nanas setiap waktunya dapat diketahui dari penghitungan viabilitas sel setiap waktu menggunakan rumus (1). Penggunaan rumus tersebut diaplikasikan pada minggu kedua sampai 
dengan minggu keempat sesuai dengan persyaratan penggunaan rumus viabilitas sel ialah pada saat terjadi penurunan jumlah sel secara eksponensial. Model linear dari aplikasi rumus viabilitas sel dapat digunakan untuk mengetahui laju destruksi sel tiap waktunya (Gambar 3). Penyimpanan dengan suhu

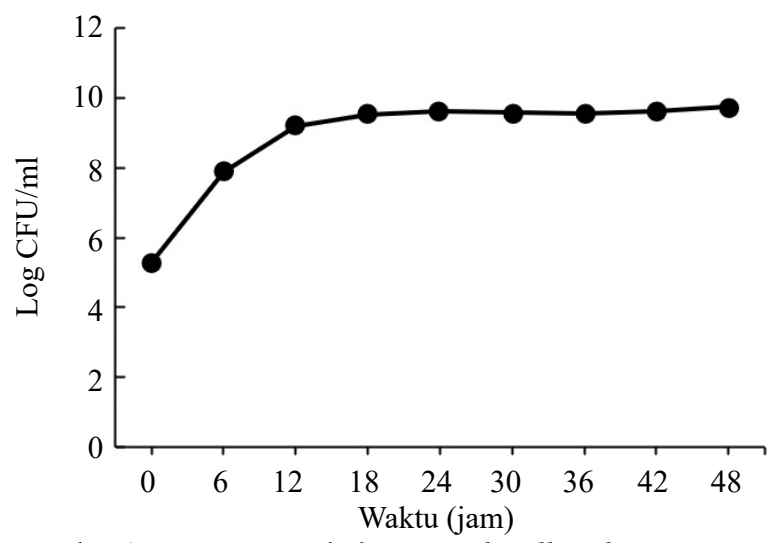

Gambar 1. Kurva Pertumbuhan Lactobacillus plantarum NHC6 dalam MRS broth
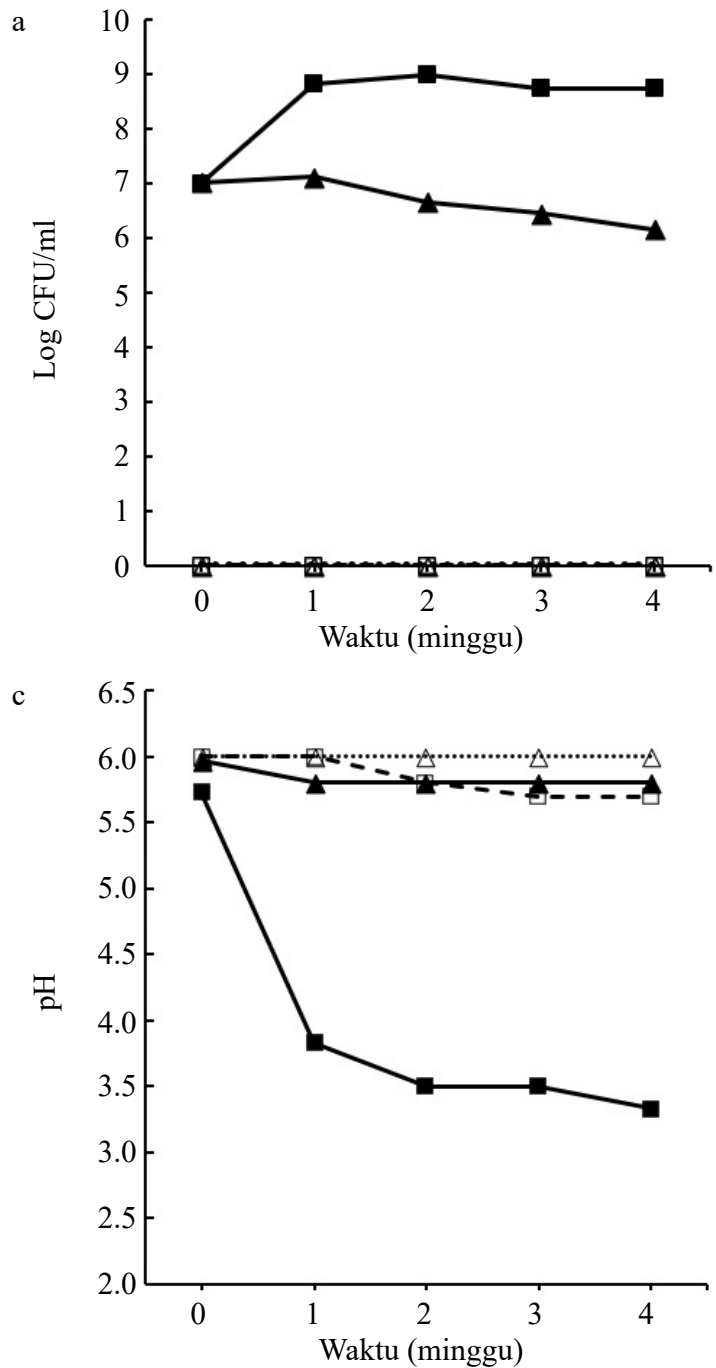

$4^{\circ} \mathrm{C}$ memiliki laju destruksi yang lebih rendah dibandingkan dengan penyimpanan suhu $10^{\circ} \mathrm{C}$. Gambar 3 memiliki hubungan dengan Gambar 2 terkait dengan jumlah mikroba dalam jus nanas yaitu penyimpanan pada suhu $4^{\circ} \mathrm{C}$ memengaruhi laju reduksi mikroba dikarenakan probiotik tidak mampu

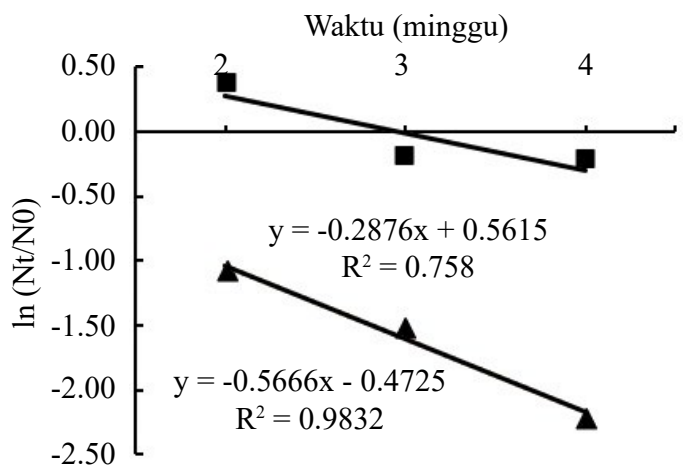

Gambar 3. Perbandingan stabilitas Lactobacillus plantarum NHC6 dalam jus nanas pada suhu simpan $4^{\circ} \mathrm{C}(\mathbf{a})$ dan $10^{\circ} \mathrm{C}($

b

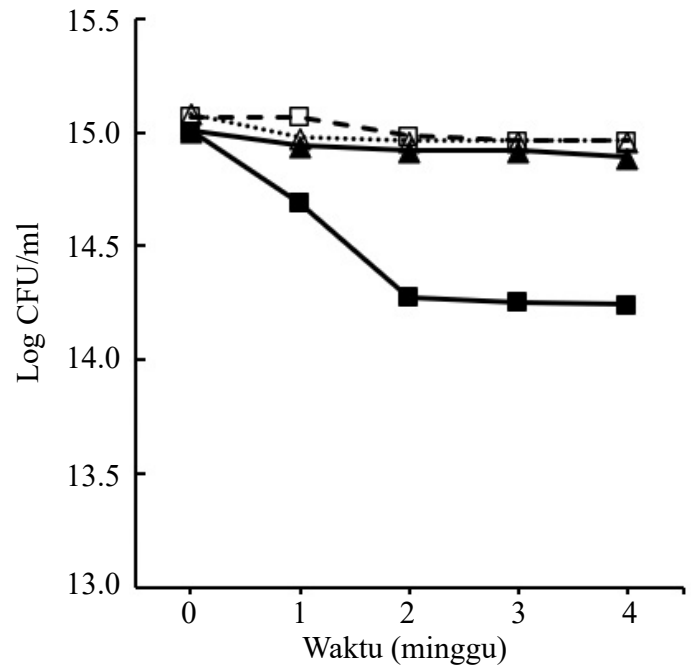

d

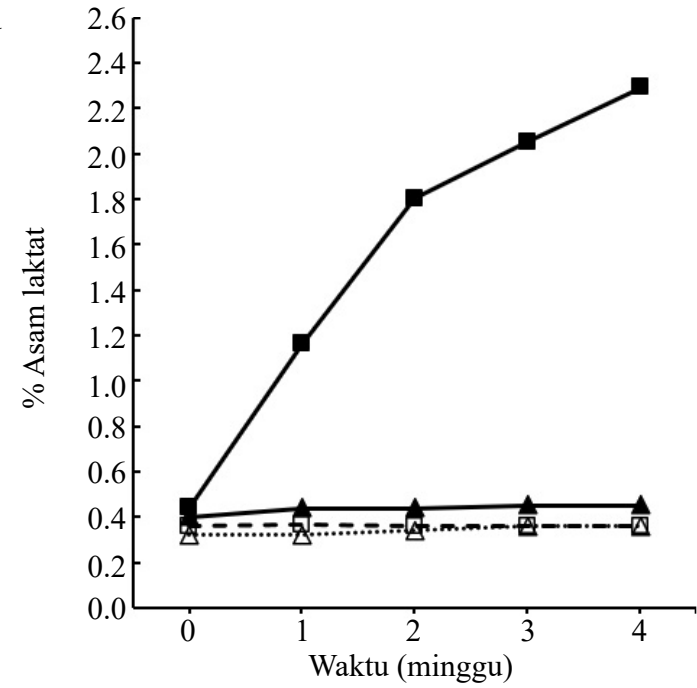

Gambar 2. (a) Perubahan jumlah sel L. plantarum NHC6, (b) perubahan persen total padatan terlarut, (c) perubahan $\mathrm{pH}$ dan, (d) perubahan persentase asam laktat dalam jus nanas selama empat minggu penyimpanan pada probiotik suhu $4^{\circ} \mathrm{C}(\boldsymbol{-}-)$, probiotik suhu $10^{\circ} \mathrm{C}(--)$, kontrol suhu $4^{\circ} \mathrm{C}(. . \wedge)$, dan kontol suhu $10^{\circ} \mathrm{C}(-\square-)$ 
untuk melakukan pertumbuhan dalam substrat, sedangkan probiotik dalam suhu $10^{\circ} \mathrm{C}$ dapat tumbuh dalam jus sampai ketersedian nutrisi mulai terbatas dan konsentrasi metabolit semakin meningkat, kemudian menyebabkan terjadinya reduksi mikroba.

Hubungan antara suhu simpan dan laju destruksi mikroba didalam jus nanas dapat diketahui dengan menggunakan persamaan Arrhenius (2). Model linear Arrhenius memperlihatkan setiap kenaikan suhu simpan akan menyebabkan laju destruksi mikrob semakin cepat (Gambar 4). Nilai dari energi aktivasi dapat ditentukan dari persamaan Arrhenius yang diperoleh (5). Ea dari persamaan (5) tersebut adalah 142.776 $\mathrm{kJ} \cdot \mathrm{mol}^{-1}$.

$$
\ln (\mathrm{k})=-17.173 *\left(1 / \mathrm{T}^{*} 10^{3}\right)+60.924
$$

Laju destruksi probiotik yang telah diketahui untuk dua perlakuan suhu dapat digunakan untuk memprediksi nilai waktu reduksi desimal mikroba dengan menggunakan rumus (3) sehingga dapat diketahui jumlah reduksi 90, 99, dan $99.9 \%$ probiotik didalam jus nanas (Tabel 1). Prediksi masa simpan probiotik diketahui dengan jumlah minimum sel bakteri di dalam jus nanas. Prediksi dilakukan dengan memprediksi kematian sel di dalam jus nanas setiap waktunya sampai dengan batas minimum jumlah sel yang menjadi standar produk probiotik. Berdasarkan dari model prediksi yang diperoleh, penyimpanan pada suhu $4^{\circ} \mathrm{C}$ akan mengalami reduksi jumlah mikroba sebanyak $90 \%$ setelah 24.47 minggu penyimpanan. Pada penyimpanan suhu $10^{\circ} \mathrm{C}$, terjadi reduksi sebesar $90 \%$ mikroba

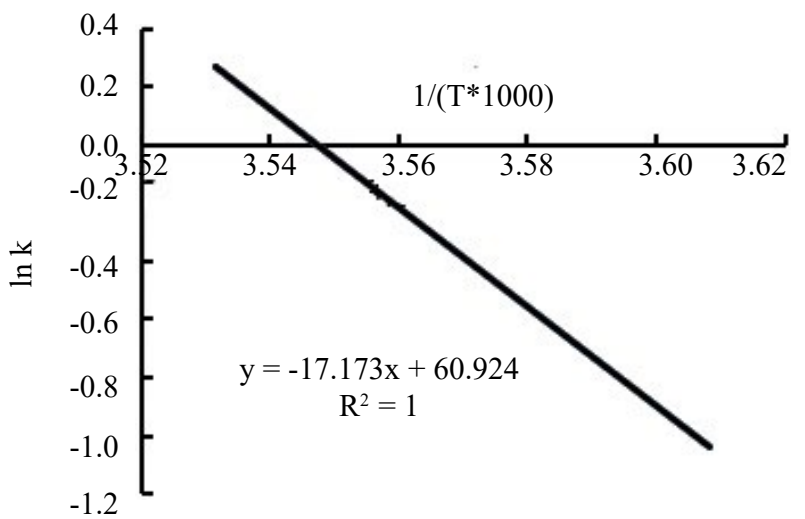

Gambar 4. Model linear Arrhenius L. plantarum NHC6 dalam jus nanas pada jus setelah 2.7 minggu penyimpanan. Hasil ini menunjukkan peningkatan suhu penyimpanan akan menyebabkan peningkatan reduksi jumlah mikroba setiap waktunya. Masa simpan probiotik diketahui berdasarkan hubungan Tabel 1 dan 2 sehingga diperoleh nilai regresi antara waktu reduksi desimal dan jumlah sel (Gambar 5). Berdasarkan jumlah minimal bakteri dalam produk probiotik, maka prediksi masa simpan minuman probiotik untuk suhu simpan $4^{\circ} \mathrm{C}$ baik digunakan hingga 28.32 minggu. Probiotik yang disimpan pada suhu $10^{\circ} \mathrm{C}$ baik digunakan sampai 8.67 minggu setelah produksi.
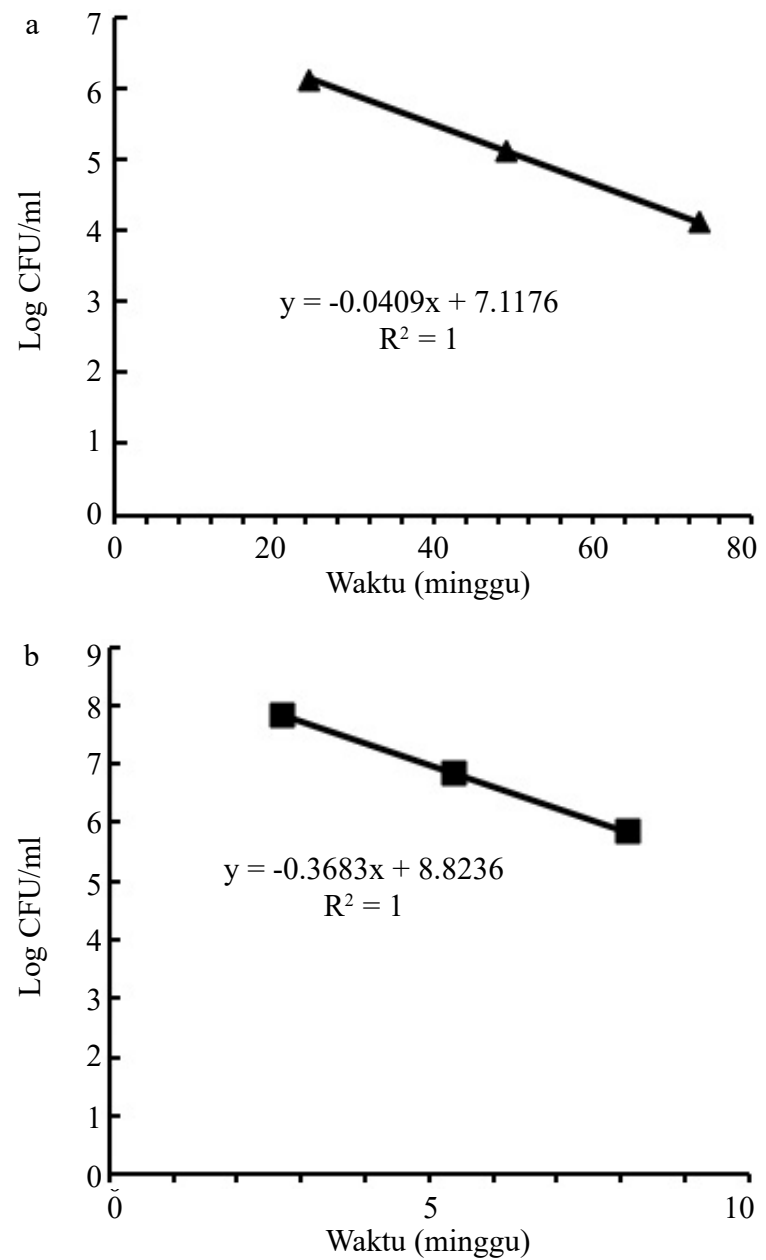

Gambar 5. Hubungan linear antara jumlah sel dengan laju destruksi L. plantarum NHC6 dalam jus nanas (a) pada suhu $4^{\circ} \mathrm{C}$ dan (b) $10^{\circ} \mathrm{C}$ untuk prediksi masa simpan probiotik jus nanas

Tabel 1. Parameter kinetik L. plantarum NHC6 dalam jus nanas terfermentasi

\begin{tabular}{llrrr}
\hline \multirow{2}{*}{$\mathrm{Suhu}\left({ }^{\circ} \mathrm{C}\right)$} & \multicolumn{3}{c}{ Waktu reduksi desimal (minggu) } \\
\cline { 3 - 5 } & $\mathrm{k}\left(\mathrm{minggu}^{-1}\right)$ & $\mathrm{D} 1$ & $\mathrm{D} 2$ & $\mathrm{D} 3$ \\
\hline 4 & 0.0941 & 24.47 & 48.94 & 73.41 \\
10 & 0.8491 & 2.71 & 5.42 & 8.14 \\
\hline
\end{tabular}

Tabel 2. Prediksi jumlah L. plantarum NHC6 dalam jus nanas setelah penyimpanan empat minggu

\begin{tabular}{lcccc}
\hline Perlakuan & Sel inisial minggu pertama & \multicolumn{3}{c}{ Waktu reduksi desimal (minggu) } \\
\cline { 3 - 5 } & $(\log \mathrm{CFU} / \mathrm{ml})$ & $\mathrm{D} 1$ & $\mathrm{D} 2$ & $\mathrm{D} 3$ \\
\hline Suhu $4{ }^{\circ} \mathrm{C}$ & 7.12 & 6.12 & 5.12 & 4.12 \\
Suhu $10^{\circ} \mathrm{C}$ & 8.83 & 7.83 & 6.83 & 5.83 \\
\hline
\end{tabular}




\section{PEMBAHASAN}

Kurva pertumbuhan L. plantarum NHC6 digunakan untuk mengetahui konsentrasi bakteri setiap waktunya. Konsentrasi bakteri merupakan parameter yang penting dalam produksi probiotik. Secara umum, produk probiotik komersial minimal harus memiliki konsentrasi bakteri $10^{6} \mathrm{CFU} / \mathrm{ml}$ atau $\mathrm{CFU} / \mathrm{gram}$ dan jumlah sel yang direkomendasikan untuk dikonsumsi supaya dapat menimbulkan manfaat kesehatan ialah $10^{8}$ sampai $10^{9} \mathrm{CFU} / \mathrm{ml}$ per hari (Kechagia et al. 2013). Manfaat kesehhatan yang ditimbulkan oleh probiotik tidak selalu bergantung kepada sel yang hidup dalam produk probiotik (Lahtinen 2012). Pada beberapa kasus tertentu, sel probiotik yang telah mengalami deaktivasi ataupun mengalami kematian juga dapat meningkatkan sistem kekebalan tubuh dengan memicu sintesis IgA (Matsuguchi et al. 2003) yang artinya dalam suatu produk probiotik sel hidup dan mati masih bermanfaat untuk kesehatan.

Jumlah bakteri yang dimasukkan kedalam jus nanas sebagai starter sebanyak $7 \log \mathrm{CFU} / \mathrm{ml}$ untuk dua perlakuan suhu. Bakteri mengalami peningkatan jumlah sel pada minggu pertama sampai kedua dan mengalami penurunan setelahnya untuk suhu penyimpanan $10^{\circ} \mathrm{C}$. Penyimpanan pada suhu $4^{\circ} \mathrm{C}$ menyebabkan bakteri mengalami penurunan jumlah sel setiap minggunya. Bakteri dalam penelitian ini termasuk dalam genus Lactobacillus yang memiliki suhu pertumbuhan tertentu yang menjadi acuan dalam penetapan suhu simpan. Genus Lactobacillus secara umum dapat tumbuh pada suhu $2-53^{\circ} \mathrm{C}$ (Pot et al. 2014). L. plantarum memiliki karakter hidup nomadic yaitu dapat hidup bebas ataupun berada dalam inang (Martino et al. 2016). Kelompok bakteri nomadic memiliki suhu optimum untuk pertumbuhan berkisar pada suhu $32-36^{\circ} \mathrm{C}$ (Duar et al. 2017). Suhu optimum akan memengaruhi pertumbuhan bakteri, suhu simpan yang mendekati suhu optimum akan lebih baik pertumbuhannya dibandingkan yang menjauhi suhu optimumnya seperti suhu simpan $4^{\circ} \mathrm{C}$ yang cenderung mengalami penghambatan pertumbuhan bakteri. Hasil pertumbuhan juga teramati menurun pada Pediococcus pentosaceus LaG1, P. pentosaceus LBF2, dan L. rhamnosus GG dalam jus nanas pada penyimpanan $4^{\circ} \mathrm{C}$ selama 4 minggu karena bakteri tidak dapat tumbuh dengan baik pada suhu simpan tersebut (AdebayoTayo dan Akpeji 2016).

Gula yang diukur pada penelitian ini ialah persen total padatan terlarut menggunakan refraktometer. Kandungan gula pada padatan terlarut jus nanas secara umum ialah berupa glukosa $(4.4 \%, \mathrm{~b} / \mathrm{v})$, fruktosa $(2.4 \%, \mathrm{~b} / \mathrm{v})$, dan disakarida $(7.4 \%$, b/v) sehingga dapat dimanfaatkan oleh bakteri (Nguyen et al. 2019). Penurunan total padatan disebabkan oleh aktifitas fermentasi substrat oleh L. plantarum NHC6. Secara umum, fermentasi substrat oleh Lactobacillus dapat dibagi menjadi dua, yaitu homofermentatif dan heterofermentatif (Zheng et al. 2015). Perbedaan dari kedua jenis fermentasi ini ialah terletak pada komposisi enzim dan hasil produk dari proses fermentasi. Homofermentatif akan menghasilkan produk dua mol asam laktat dan dua mol ATP sedangkan pada heterofermentatif menghasilkan laktat, etanol, $\mathrm{CO}_{2}$, dan satu molekul ATP untuk setiap mol glukosa (Gänzle 2015). L. plantarum termasuk jenis metabolisme homofermentatif yang hanya akan menghasilkan produk berupa asam laktat (Zheng et al. 2015). Proses homofermentasi yang dilakukan L. plantarum NHC6 dalam jus nanas hanya akan menghasilkan asam laktat sebagai produk hasil metabolisme primernya.

Fermentasi substrat menyebabkan konsentrasi asam laktat meningkat dan $\mathrm{pH}$ jus turun. Sebelum fermentasi, $\mathrm{pH}$ jus dinaikkan sampai menjadi 6 yang bertujuan untuk memberikan kondisi $\mathrm{pH}$ optimal untuk pertumbuhan L. plantarum (Giraud et al. 1991). Jus nanas komersial memiliki $\mathrm{pH}$ berkisar 3.5-4.0, namun pada perlakuan $10^{\circ} \mathrm{C}$ setelah empat minggu jus nanas memiliki $\mathrm{pH}$ relatif lebih rendah daripada jus nanas komersial yaitu 3.3 namun masih dapat dikonsumsi. Penurunan $\mathrm{pH}$ disebabkan oleh proses fermentasi yang menghasilkan produk berupa asam laktat karena $L$. plantarum melakukan proses homofermentasi dalam pengubahan substrat menjadi laktat (Zheng et al. 2015).

Asam laktat mengalami peningkatan pada probiotik dengan penyimpanan di suhu $10^{\circ} \mathrm{C}$. Persen asam laktat mengalami peningkatan setiap minggunya dan pada minggu keempat persentase asam laktat mencapai $2.29 \%(\mathrm{~b} / \mathrm{v})$ dalam jus nanas. Asam laktat merupakan salah satu asam organik yang dapat menghambat pertumbuhan mikroba lain. Penghambatan pertumbuhan terjadi dikarenakan asam organik mereduksi $\mathrm{pH}$ intraseluler dan menghambat transport aktif dari kelebihan proton internal sehingga dibutuhkan konsumsi ATP yang menyebabkan berkurangnya energi untuk proses seluler (Ricke 2003). Asam organik berpengaruh pada dinding sel bakteri, membran sitoplasma, dan fungsi spesifik metabolisme (replikasi dan sintesis protein) yang dapat menyebabkan gangguan dan kematian pada mikroba patogen (Surendran et al. 2017). Asam laktat yang dihasilkan membuat iklim mikro sekitar menjadi tidak sesuai untuk pertumbuhan bakteri patogen (Dittoe et al. 2018). Konsentrasi asam laktat 0.5\% 
(v/v) dapat menghambat pertumbuhan patogen seperti Salmonella spp., E. coli, ataupun Listeria monocytogenes (Wang et al. 2015). Probiotik yang disimpan pada suhu $10^{\circ} \mathrm{C}$ menghasilkan asam laktat yang dapat menghambat pertumbuhan patogen pada produk probiotik.

Pada saat suhu simpan meningkat, maka nilai dari laju destruksi juga meningkat (nilai $\mathrm{k} 4^{\circ} \mathrm{C}$ $<10^{\circ} \mathrm{C}$ ). Desktruksi jumlah mikroba berkaitan dengan kenaikan suhu, hal ini sama dengan penelitian yang dilakukan oleh Muller et al. (2013) bahwasanya destruksi probiotik akan meningkat seiring dengan kenaikan suhu simpan. Kenaikan suhu simpan berkaitan dengan metabolisme bakteri. Apabila suhu simpan mendekati suhu optimum pertumbuhan bakteri, maka aktivitas bakteri dalam substrat akan meningkat. Pertumbuhan bakteri yang cepat akan berpengaruh terhadap ketersediaan substrat tumbuh yang dapat menyebabkan jumlah sel bakteri tereduksi pada saat nutrisi tidak tersedia di dalam substrat.

Simpulan dari penelitian ini dengan suhu penyimpanan yang berbeda pada probiotik jus nanas memengaruhi waktu reduksi dari jumlah mikroba yang hidup dalam jus nanas. Produk probiotik jus nanas yang disimpan pada suhu $4^{\circ} \mathrm{C}$ memiliki masa simpan yang lebih lama dibandingkan $10^{\circ} \mathrm{C}$. Peningkatan suhu simpan berpengaruh terhadap metabolisme bakteri dalam menggunakan substrat tumbuh yang membuat terjadinya perubahan pada karakter jus nanas. Prediksi masa simpan minuman probiotik untuk suhu simpan $4^{\circ} \mathrm{C}$ baik dikonsumsi hingga umur simpan 28.32 minggu, sedangkan pada suhu $10^{\circ} \mathrm{C}$ baik digunakan sampai 8.67 minggu setelah produksi berdasarkan konsentrasi minimum probiotik dalam jus nanas $\left(\geq 10^{6} \mathrm{CFU} /\right.$ $\mathrm{ml})$. Jus nanas dapat digunakan sebagai substrat untuk pertumbuhan probiotik dari Lactobacillus plantarum NHC6.

\section{DAFTAR PUSTAKA}

[FAO/WHO] Food and Agriculture Organization/World Health Organization of United Nation. 2006. Report of a joint FAO/WHO expert consultation on evaluation of health and nutritional properties of probiotics in food including powder milk with live lactic acid bacteria. Rome: FAO.

Adebayo-Tayo B, Akpeji S. 2016. Probiotic viability, physiochemical and sensory properties of probiotic pineapple juice. Fermentation 2:1-11.

Bienenstock J, Kunze W, Forsythe P. 2015. Microbiota and the gut-brain axis. Nutr Rev 7:28-31.

Bron PA, Kleerebezem M, Brummer RJ, Cani PD, Mercenier A, MacDonald TT, Garcia-Rodenas CL, Wells JM. 2017. Can probiotics modulate human disease by impacting intestinal barrier function?. Br J Nutr 117:93-107.

Camara MM, Diez C, Torija ME. 1996. Free sugar determination by HPLC in pineapple product. Z Lebensm Unters Forsch 202:233-237.
Dittoe DK, Ricke SC, Kiess AS. 2018. Organic acids and potential for modifying the avian gastrointestinal tract and reducing pathogens and disease. Front Vet Sci 5:216. DOI:10.3389/ fvets.2018.00216

Duar RM, Frese SA, Lin XB, Fernando SC, Burkey TE, Tasseva G, Peterson DA, Blom J, Wenzel CQ, Szymanski CM. 2017. Experimental evaluation of host adaptation of Lactobacillus reuteri to different vertebrate species. Appl Environ Microb 83:1-17.

Flint HJ, Scott KP, Louis P, Duncan SH. 2012. The role ofthe gut microbiota in nutrition and health. Nat Rev Gastroenterol Hepatol 9:577-589.

Gänzle MG. 2015. Lactic metabolism revisited: metabolism of lactic acid bacteria in food fermentations and food spoilage. Curr Opin Food Sci 2:106-117.

Giraud E, Lelong B, Raimbault M. 1991. Influence of $\mathrm{pH}$ and initial lactate concentration on growth of Lactobacillus plantarum. Applied Microbiol Biotech 36:96-99.

Hossain MF, Akhtar S, Anwar M. 2015. Nutritional value and medicinal benefits of pineapple. IJNFS 4:84-88.

Karczewski J, Troost FJ, Konings I, Dekker J, Kleerebezem M, Brummer RJ, Wells JM. 2010. Regulation of human epithelial tight junction proteins by Lactobacillus plantarum in vivo and protective effects on the epithelial barrier. Am J Physiol Gastrointest Liver Physiol 298:851859.

Kechagia M, Basoulis D, Konstantopoulou S, Dimitriadi D, Gyftopoulou K, Skarmoutsou N, Fakiri EM. 2013. Health benefits of probiotics: a review. ISRN Nutrition 2013:1-7.

Kim MH, Kang SG, Park JH, Yanagisawa M, Kim CH. 2013. Shortchain fatty acids activate GPR41 and GPR43 on intestinal epithelial cells to promote inflammatory responses in mice. Gastroenterology 145:396-406.

Konig J, Wells J, Cani PD, Garcia-Rodenas CL, MacDonald T, Mercenier A, Whyte J, Troost F, Brummer RJ. 2016. Human intestinal barrier function in health and disease. Clin Transl Gastroenterol 7:e196.

Kosin B, Rakshit SK. 2006. Criteria for production of probiotics. Food Technol Biotech 44:371-379.

Lagnika C, Adjovi YCS, Lagnika L, Gogohounga FO, DoSacramento O, Koulony RK, Sanni A. 2017. Effect of combining ultrasound and mild heat treatment on physicochemical, nutritional quality and microbiological properties of pineapple juice. Food Nutr Sci 8:227-241.

Lahtinen SJ. 2012. Probiotic viability - does it matter?. Microbial Eco Health Disease 23:1-14.

Martino ME, Bayjanov JR, Caffrey BE, Wels M, Joncour P, Hughes S, Gillet B, Kleerebezem M, Hijum SAFT, Leulier F. 2016. Nomadic lifestyle of Lactobacillus plantarum revealed by comparative genomics of 54 strains isolated from different habitats. Environ Microbiol 18:4974-4989.

Matsuguchi T, Takagi A, Matsuzaki T, Nagaoka M, Ishikawa K, Yokokura T, Yoshikai Y. 2003. Lipoteichoic acids from Lactobacillus strains elicit strong tumor necrosis factor alpha-inducing activities in macrophages through Toll-like receptor 2. Clin Diagn Lab Immunol 10:259-66.

Mazumder MAR, Aziz MG, Uddin MB, Shikder MFH. 2009. Effect of enzymatic liquefaction and hydrocolloids on physicochemical properties of cloudy pineapple juices. Intl J Bio Res 6:80-91.

Moraru D, Blanca I, Segal R. 2007. Probiotic vegetable juices. Food Technol 4:87-91.

Muller C, Busignies V, Mazel V, Forestier C, Nivoliez A. 2013. Mechanistic approach to stability studies as a tool for the optimization and development of new products based on L. rhamnosus $\operatorname{Lcr} 35 \AA$ in compliance with current regulations. PLOS ONE 8:1-6.

Nguyen BT, Bujna , Fekete N, Tran ATM, Rezessy-Szabo JM, Prasad R, Nguyen QD. 2019. Probiotic beverage from pineapple juice fermented with Lactobacillus and Bifidobacterium strains. Front Nutr 6:1-7.

Pot B, Felis GE, Bruyne K De, Tsakalidou E, Papadimitrou K, Leisner J, Vandamme P. 2014. The genus Lactobacillus. In: Holzapfel WH, Wood BJB (Eds.). Lactic Acid Bacteria. Chichester: John Wiley and Sons. 
Riani CR. 2020. Isolasi bakteri asam laktat sebagai probiotik asal jus nanas [Tesis]. Bogor, Indonesia: Institut Pertanian Bogor. Ricke SC. 2003. Perspectives on the use of organic acids and short chain fatty acids as antimicrobials. Poult Sci 82:632-639.

Suhaeni. 2018. Uji total asam dan organoleptik yogurt katuk (Sauropus androgyneus). Jurnal Dinamika 9:21-28.

Surendran NM, Amalaradjou MA, Venkitanarayanan K. 2017. Antivirulence Properties of Probiotics in Combating Microbial Pathogenesis. New York: Elsevier.
Wang C, Chang T, Yang H, Cui M. 2015. Antibacterial mechanism of lactic acid on physiological and morphological properties of Salmonella enteriditis, Escherichia coli and Listeria monocytogenes. Food Control 47:231-236.

Zheng J, Ruan L, Sun M, Gänzle M. 2015. A Genomic view of lactobacilli and pediococci demonstrates that phylogeny matches ecology and physiology. Appl Environ Microbiol 81:7233-7243. 